Research Article

\title{
Source Identification and Spatial Distribution of Heavy Metal Concentrations in Shallot Fields in Brebes Regency, Central Java, Indonesia
}

\author{
Triyani Dewi, ${ }^{1,5}$ Edhi Martono, ${ }^{2}$ Eko Hanudin $\mathbb{D}^{0},{ }^{3}$ and Rika Harini ${ }^{4}$ \\ ${ }^{1}$ Indonesian Agricultural Environment Research Institute, Jl. Jakenan-Jaken PO.BOX 05, Pati, Central Java, Indonesia \\ ${ }^{2}$ Department of Plant Protection, Faculty of Agriculture, Universitas Gadjah Mada, Bulaksumur, Yogyakarta 55281, Indonesia \\ ${ }^{3}$ Department of Soil Science, Faculty of Agriculture, Universitas Gadjah Mada, Bulaksumur, Yogyakarta 55281, Indonesia \\ ${ }^{4}$ Department of Environmental Geography, Faculty of Geography, Universitas Gadjah Mada, Sekip Utara, Bulaksumur, \\ Yogyakarta 55281, Indonesia \\ ${ }^{5}$ Graduate School of Environmental Science, Universitas Gadjah Mada, Pogung 6 Sinduadi Yogyakarta 55284, Indonesia
}

Correspondence should be addressed to Eko Hanudin; ekohanudin@ugm.ac.id

Received 18 April 2021; Revised 18 July 2021; Accepted 12 August 2021; Published 25 August 2021

Academic Editor: Rafael Clemente

Copyright $\odot 2021$ Triyani Dewi et al. This is an open access article distributed under the Creative Commons Attribution License, which permits unrestricted use, distribution, and reproduction in any medium, provided the original work is properly cited.

Shallots have been widely planted as the primary commodity crop in Brebes Regency, Central Java, Indonesia. Information on the distribution of heavy metals in the shallot fields of Brebes Regency, Central Java, Indonesia, is not yet available. Hence, the present study was conducted to identify the concentration and spatial distribution of several heavy metals $(\mathrm{Pb}, \mathrm{Cd}, \mathrm{Co}, \mathrm{Cr}$, and $\mathrm{Ni}$ ) and their possible sources in the shallot fields through a field survey and a series of laboratory and statistical tests. The total concentration of heavy metals was analyzed from 184 sampling points of the shallot fields in Brebes Regency, Central Java, Indonesia, during the dry season from August to October 2019. The heavy metals concentration was as follows: $\mathrm{Cr}>\mathrm{Ni}>\mathrm{Pb}>\mathrm{Co}>\mathrm{Cd}$. The values of total $\mathrm{Pb}, \mathrm{Cd}, \mathrm{Co}, \mathrm{Cr}$, and $\mathrm{Ni}$ concentrations in the soils were 7.84-18.94, 0.99-2.31, 3.02-9.98, 10.40-49.55, and $10.17-26.62 \mathrm{mg} \mathrm{kg}^{-1}$, respectively. All these concentration values of heavy metals are still lower than the critical values for agricultural soils and lower than the topsoil background values except $\mathrm{Cd}$. Based on the concentration of heavy metals, the shallot fields in Brebes Regency, Central Java, are classified as uncontaminated soils. Multivariate and geostatistical analyses were employed to determine and describe the metals' origin. $\mathrm{Pb}, \mathrm{Cr}$, and $\mathrm{Ni}$ mainly originate from a natural source, while $\mathrm{Cd}$ and $\mathrm{Co}$ are from anthropogenic sources (agricultural practices and industry).

\section{Introduction}

Heavy metals are among the potentially harmful environmental pollutants in agricultural soils. Their presence in the environment is reported to come from natural and anthropogenic sources. Their natural sources are rocks, parent materials, vegetation, and volcanogenic particles, while the anthropogenic sources include transportation, mining, industrial activities, sewage, and wastewater irrigation, uncontrolled uses of chemical fertilizers and pesticides, and residual organic matters [1-3]. Atmospheric deposition is also a known source of pollution in urban areas and soils cultivated for agricultural purposes [4-6].
Heavy metals may accumulate in substantial amounts in agricultural soils following excessive agrochemical (pesticide and fertilizer) and ameliorant applications, atmospheric, and agriculture machinery usage. It is estimated that the contribution of anthropogenic sources is higher than natural sources $[4,7]$. Here, cadmium $(\mathrm{Cd})$, lead $(\mathrm{Pb})$, and chromium (Cr) can be found in increasingly high levels due to the unchecked use of agricultural chemicals. When taken up by plant roots, they can damage the crops and reduce overall agricultural yields. Most importantly, heavy metal accumulation contaminates the environment that will, in turn, disturb the food chain and diminish groundwater quality $[8,9]$. 
Brebes Regency is one of the most important shallot production centers in Java, if not Indonesia, that practices intensive agriculture, including uncontrolled pesticides and fertilizers. Generally, local farmers plant shallots three times a year and one-time planting for a rotation system involving other crops such as rice, chili, corn, and eggplant. However, the agricultural lands have not yet reached their optimal productivity because of some constraints such as low soil fertility, plant disease outbreaks, and pests. To overcome these problems, local farmers generally use chemical fertilizers and pesticides, but, in practice, it is found that their applications are excessive and uncontrolled, thus potentially polluting the environment. During its growth, shallot absorbs nutrients from the soil, which may include heavy metals that are later transferred to agricultural products. As contaminants, they can decrease crop yields and quality and food safety. On the other hand, shallot farming is expected to implement environmentally friendly practices to achieve sustainable agriculture in the future [10-13].

Many researchers have studied agricultural land in Brebes Regency: for example, organochlorine and organophosphate insecticide residues found in rice plants, soil, and water samples [14]; land suitability and availability evaluation for shallot farming development $[15,16]$; degradation of soil quality due to pesticide application [11]; farmer's behavior in using pesticide and shallot cultivation $[17,18]$; and $\mathrm{Pb}$ concentration in shallot bulbs [19]. No studies were reported on the spatial distribution of heavy metals in shallot fields in Brebes Regency, Central Java, Indonesia. Therefore, the present study is considered necessary.

A multivariate analysis is a statistical method for analyzing data that consist of many interdependent variables. Principal component analysis (PCA) has been widely used in geochemical applications to identify contamination sources and apportion natural and anthropogenic contributions. Cluster analysis (CA) is often coupled with PCA to check the results and provide a grouping of individual parameters and variables. A combination of PCA and GIS techniques in soil studies has been used to identify the spatial interpolation and variability-measured soil variables. Geostatistics is used to construct regional distribution maps, which are then compared to the geographical, geologic, and land-use regional using geographical information system (GIS) software. Based on GIS, the spatial distribution of metals can be used to identify their possible sources and contamination or risk hotspot [20-22].

This research aims to identify the spatial distributions and concentrations of several heavy metals $(\mathrm{Pb}, \mathrm{Cd}, \mathrm{Co}, \mathrm{Ni}$, and $\mathrm{Cr}$ ) and investigate possible sources of these contaminants in shallot fields in Brebes Regency, Central Java Province, Indonesia.

\section{Materials and Methods}

2.1. Study Sites. The study was conducted in Brebes Regency on the northern coast of Central Java, Indonesia, stretching from $6^{\circ} 44^{\prime}$ to $7^{\circ} 21^{\prime} \mathrm{S}$ and $108^{\circ} 41^{\prime}$ to $109^{\circ} 11^{\prime}$ E. A map showing the soil sampling points is shown in Figure 1. Brebes Regency has a tropical climate. Based on the 2019 data, Brebes receives a total rainfall of $3,729 \mathrm{~mm}$, with the highest occurring in January and February, $670 \mathrm{~mm}$ and $686 \mathrm{~mm}$, respectively. There are approximately 172 rainy days, most of which are recorded in March and December, counted as 29 days. Inceptisols (USDA soil taxonomy classification) are the predominant soil developing in the research location. Brebes covers an area of $1,769.62 \mathrm{~km}^{2}$, $38.1 \%$ of which are agricultural lands and the remaining $61.9 \%$ are for nonagricultural uses. The regency was selected as the research location based on its shallot productivity, and the persistent practice of excessive fertilizer and pesticide applications may cause heavy metal contamination and land degradation in the shallot fields.

2.2. Soil Sampling. The soil sampling was conducted during the dry season period from August to October 2019. In total, 184 topsoil samples (depth $0-20 \mathrm{~cm}$ ) and five subsamples were collected from 50 to 100 acres of land using a soil auger. These soil samples were thoroughly mixed and bulked. The bulk samples were reduced to about $1-2 \mathrm{~kg}$ and labeled according to the soil observation procedure. GPS (global position system) was used to record the soil sampling coordinates. Upon soil collection, all samples were first airdried in the shade, ground with a mortar and pestle, filtered with a $0.5 \mathrm{~mm}$ sieve, and then analyzed at an integrated laboratory at the Indonesian Agricultural Environment Research Institute (IAERI), Jakenan, Central Java, Indonesia.

2.3. Chemical Analysis. Soil $\mathrm{pH}$ was measured with a $\mathrm{pH}$ meter using a water extract and a soil-water ratio of $1: 2.5$ (weight/volume). The total heavy metal contents ( $\mathrm{Pb}, \mathrm{Cr}, \mathrm{Co}$, $\mathrm{Cd}$, and $\mathrm{Ni}$ ) in the soil were determined using the $\mathrm{HNO}_{3}-\mathrm{HClO}_{4}$ mixture for digestion. The resultant liquid extract was measured with an atomic absorption spectrometer (AAS) and then compared with the standard series of each heavy metal. The heavy metal levels were measured at their respective wavelengths: $\mathrm{Pb}=217.0 \mathrm{~nm}, \mathrm{Cd}=228.8 \mathrm{~nm}$, $\mathrm{Co}=240.7 \mathrm{~nm}, \mathrm{Ni}=232.0 \mathrm{~nm}$, and $\mathrm{Cr}=357.9 \mathrm{~nm}$. They were calculated using their respective calibration curves. For each heavy metal, the absorbance of the extracted solution was subject to seven replicate measurements with an AAS at two different times to obtain the concentration values. The accuracy limit is \% recovery $=75-125 \%$ [23]. Pb, Cd, Co, Cr, and $\mathrm{Ni}$ concentrations were calculated using the following formula:

$$
\text { total heavy metal content }\left(\mathrm{mg} \cdot \mathrm{kg}^{-1}\right)=C \text { curve } x \frac{v}{w} x f p x f k \text {, }
$$

where $C$ curve is the heavy metal concentration obtained from the AAS $\left(\mathrm{mg} \mathrm{kg}^{-1}\right), V$ is the final extractant volume $(\mathrm{ml}), W$ is the sample weight $(\mathrm{g}), f p$ is the dilution factor, and $f k$ is the correction factor for sample moisture content. The limit of detection (LoD) for each metals was $\mathrm{Pb}=$ $0.0261 \mathrm{mg} \mathrm{kg}^{-1}, \mathrm{Cd}=0.0196 \mathrm{mg} \mathrm{kg}^{-1}, \mathrm{Cr}=0.0266 \mathrm{mg} \mathrm{kg}^{-1}$, $\mathrm{Co}=0.0094 \mathrm{mg} \mathrm{kg}^{-1}$, and $\mathrm{Ni}=0.0083 \mathrm{mg} \mathrm{kg}^{-1}$. 

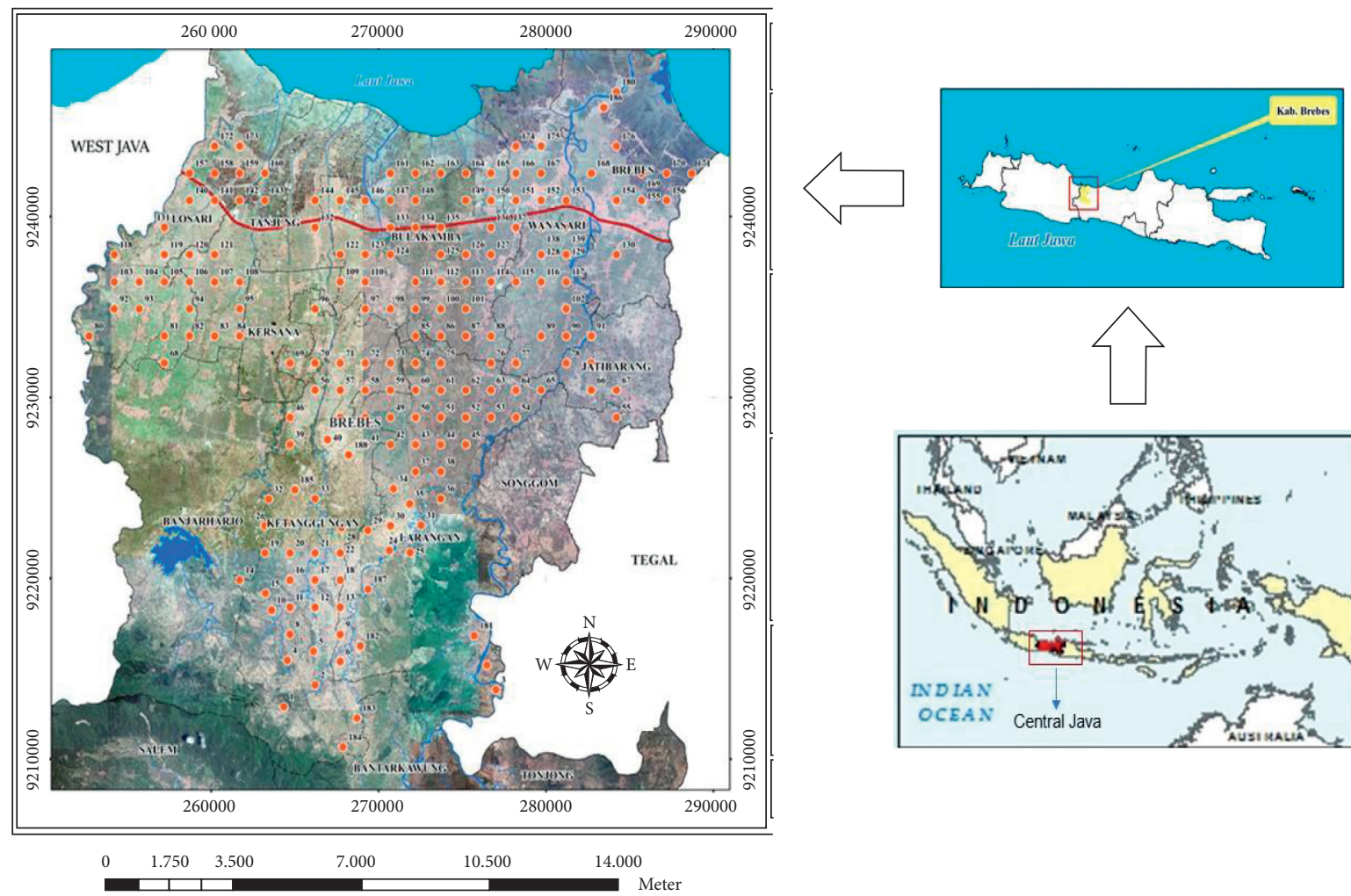

FIgURE 1: The study location and the soil sampling points in Brebes Regency, Central Java, Indonesia.

2.4. Data Analysis. The statistical analysis was performed on Minitab 16 program. The raw data of each heavy metal concentration were analyzed for their normal distribution using the Kolmogorov-Smirnov test. The research employed three multivariate analyses. Correlation analysis determined the relationship between heavy metals, principal component analysis (PCA) of similar metal groups identified their possible sources, and cluster analysis grouped the heavy metals observed based on their sources. Geostatistics is a set of statistical tools for inputting and processing temporal and spatial data by coordinates [24-26]. The spatial distributions (maps) of the five heavy metal levels in the shallot fields were generated with simple kriging interpolation on ArcGIS 10.4.

\section{Results and Discussion}

3.1. Descriptive Statistics and Heavy Metal Concentrations in the Soil. This section summarizes the statistical analysis results of the heavy metal concentration, soil $\mathrm{pH}$, soil organic carbon (SOC), and cation exchange capacity (CEC) levels in the shallot fields in Brebes Regency, Central Java (Table 1), and the heavy metal concentrations by soil samples (Figure 2). The mean concentrations of the heavy metals in the soil ranged from $1.78 \pm 0.27$ to $21.52 \pm 7.42 \mathrm{mg} \mathrm{kg}^{-1}$ in the ascending order of $\mathrm{Cr}>\mathrm{Ni}>\mathrm{Pb}>\mathrm{Co}>\mathrm{Cd}$. Their background values are $59.5,29.0,27.0,11.3$, and $0.41 \mathrm{mg} \mathrm{kg}^{-1}$; thus, all mean concentrations are lower than their respective background values, except for $\mathrm{Cd}$.

The soil $\mathrm{pH}$ ranged from 5.02 to 7.60 , with $51.6 \%$ of the samples below $6.5,47.3 \%$ between 6.5 and 7.5 , and only $1.1 \%$ above 7.5. The factors influencing soil $\mathrm{pH}$ are parent material, vegetation type, mineral composition, organic matter, climate, and human activities. The parent material's mineral composition is not a sole determinant of this property; human activities such as long-term chemical fertilization (mainly nitrogen) produce ammonium sulfate and lime that can change soil pH [28-30].

SOC contents in shallot fields are between 0.35 and $3.30 \%$, generally $69 \%$ classified as very low $(<1 \%), 30 \%$ low between 2 and $3 \%$, and only $1 \%$ classified as moderate if SOC is between 2 and 3\%. The CEC values ranged from 11.07 to $62.15 \mathrm{cmol} \mathrm{(+)} \mathrm{kg}^{-1}$ with low to very high categories. Soil organic carbon improves the physical properties of the soil. It increases the cation exchange capacity (CEC) and the water-holding capacity. Besides, it contributes to the structural stability of clay soils by helping to bind particles into aggregates. Cation exchange capacity (CEC) is the maximum quantity of total cations that a soil can hold at a given $\mathrm{pH}$ value, available for exchange with the soil solution. CEC is used to measure fertility, nutrient retention capacity, and the capacity to protect groundwater from cation contamination. The relationship between CEC and SOC is generally affected by soil $\mathrm{pH}$ and local climate, largely the condition of soil physicochemical [31].

A low standard deviation means that the heavy metal concentrations are dispersed homogenously in the research location. The skewness values of $\mathrm{Pb}, \mathrm{Cd}, \mathrm{Co}$, and $\mathrm{Ni}$ were between -1 and 1, indicating normal distribution. Except for $\mathrm{Cr}$, all heavy metals had kurtosis values lower than 1 and showed normal and platykurtic distribution. CV (coefficient 
TABle 1: Statistical analysis results of heavy metal concentrations in the soil of shallot fields in Brebes Regency, Central Java Province, Indonesia.

\begin{tabular}{|c|c|c|c|c|c|c|c|c|c|c|}
\hline Variables & $n$ & Mean & $\begin{array}{c}\text { Min } \\
\mathrm{mg} \mathrm{kg}^{-1}\end{array}$ & Max & $\mathrm{SD}$ & $\begin{array}{c}\mathrm{CV} \\
\% \\
\end{array}$ & Skewness & Kurtosis & $\begin{array}{c}\text { BGV } \\
\mathrm{mg} \mathrm{kg}^{-1}\end{array}$ & K-S test \\
\hline $\mathrm{Pb}$ & 184 & 12.53 & 7.84 & 18.94 & 2.50 & 19.95 & 0.4 & -0.45 & 27.0 & 0.058 \\
\hline $\mathrm{Cd}$ & 184 & 1.78 & 0.99 & 2.31 & 0.27 & 15.00 & -0.75 & 0.48 & 0.41 & 0.095 \\
\hline $\mathrm{Co}$ & 184 & 6.33 & 3.02 & 9.98 & 2.17 & 34.34 & 0.06 & -1.34 & 11.3 & 0.092 \\
\hline $\mathrm{Ni}$ & 184 & 16.22 & 10.17 & 26.62 & 3.53 & 21.73 & 0.48 & -0.35 & 29.0 & 0.073 \\
\hline $\mathrm{Cr}$ & 184 & 21.52 & 10.40 & 49.55 & 7.42 & 34.50 & 1.33 & 1.86 & 59.5 & 0.117 \\
\hline $\mathrm{pH}$ & 184 & 6.44 & 5.02 & 7.60 & 0.50 & 7.80 & -0.27 & -0.16 & - & 0.058 \\
\hline SOC $^{\mathrm{e}}$ & 184 & 0.91 & 0.35 & 3.30 & 0.37 & 40.35 & 2.70 & 11.66 & - & 0.169 \\
\hline $\mathrm{CEC}^{\mathrm{f}}$ & 184 & 39.10 & 11.07 & 62.15 & 8.33 & 21.29 & -0.15 & 0.39 & - & 0.061 \\
\hline
\end{tabular}

SD, standard deviation; CV, coefficient of variation (\%); BGV, background contents [27]; K-S, Kolmogorov-Smirnov test; SOC, soil organic carbon (\%); CEC, cation exchange capacity $\left(\mathrm{cmol}(+) \mathrm{kg}^{-1}\right)$.

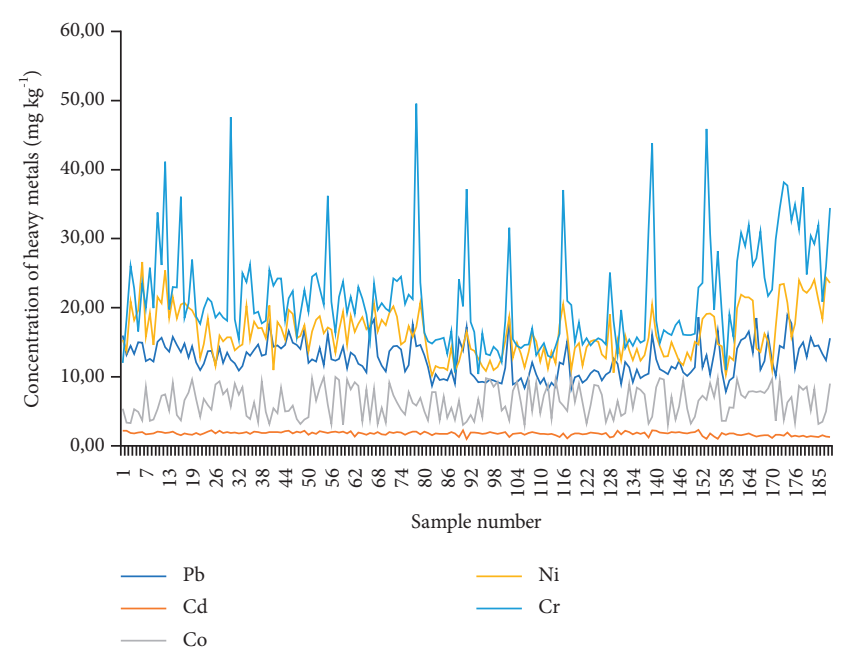

Figure 2: Heavy metal concentrations of the soil samples taken in the shallot fields in Brebes Regency, Central Java, Indonesia.

of variation) demonstrates disparate indicator measures. A low CV indicates that agricultural soils are contaminated with naturally occurring heavy metals, whereas a high CV is usually associated with heavy metals of anthropogenic sources [32-34]. The CVs of $\mathrm{Pb}, \mathrm{Cd}$, and $\mathrm{Ni}$ were $19.95 \%$, $15.00 \%$, and $21.73 \%$ (low variation, $\mathrm{CV}<25 \%$ ), meaning that, in the research location, these elements are sourced naturally (pedogenic processes and parent materials). Meanwhile, the CVs of Co and Cr were $34.34 \%$ and $34.50 \%$ (moderate variation, $25 \%<\mathrm{CV}<75 \%$ ), indicating anthropogenic roles in $\mathrm{Co}$ and $\mathrm{Cr}$ entries into the soil.

\subsection{Correlation Coefficient Analysis Results of Heavy Metal} Concentrations. Correlation analysis defines the relation between several variables and helps determine the factors influencing the source of an element. A significant and positive correlation between heavy metals in the soil indicates a similar source of contamination. The Pearson correlation coefficients for each heavy metal pair is at a significance level of $p<1 \%$. Pb-Ni (0.622), $\mathrm{Pb}-\mathrm{Cr}$ (0.577), and $\mathrm{Ni}-\mathrm{Cr}(0.636)$ have a very significant and positive correlation $(p<0.01)$; soil $\mathrm{pH}$ also strongly correlated with soil CEC (0.202) (Table 2); these metal pairs are assumed to come from the same source.
Meanwhile, Cd-Cr has a very significant and negative correlation (-0.292): the higher the Cd content, the lower the $\mathrm{Cr}$ presence in the soil.

The research found that $\mathrm{Ni}$ and $\mathrm{Cr}$ were intercorrelated. It is believed to be associated with the type and amount of rock, allowing soil formation from rock layers. Besides, $\mathrm{Ni}$ and $\mathrm{Cr}$ can also come from anthropogenic sources, limestone, manure, and fertilizers, in which $\mathrm{Ni}$ and $\mathrm{Cr}$ result in the soil parent material with a different concentration in soils $[35,36]$.

\subsection{Principal Component Analysis (PCA) Results.} Principal component analysis was used to determine the origin of the soil contaminants. The PCA results and the loading plot of the five heavy metals are given in Table 3 and Figure 3. Table 3 provides that the eigenvalues of the two extracted components were higher than 1.0. The two components (PC1 and PC2) explained $67.10 \%$ of the total variance. According to the principal component matrix (Table 4), $\mathrm{Pb}, \mathrm{Ni}$, and $\mathrm{Cr}$ were included in $\mathrm{PC} 1$, which explained $45 \%$ of the total variance. Meanwhile, PC2 consisted of Cd (negative loading) and Co (positive loading) and explained $22.1 \%$ of the total variance.

$\mathrm{PC} 1$, consisting of $\mathrm{Pb}, \mathrm{Ni}$, and $\mathrm{Cr}$, comes from the same natural source, such as lithogenic components controlled by parent materials. This finding is also confirmed in previous studies that report low $\mathrm{Pb}, \mathrm{Ni}$, and $\mathrm{Cr}$ contaminations from natural sources $[20,37,38]$. Based on the correlation coefficient and PCA results, $\mathrm{Cd}$ and $\mathrm{Co}$ in the second component (PC2) are not intercorrelated. Cd metal is mainly derived from anthropogenic sources, e.g., long-term applications of fertilizer, pesticide, and organic manure [39-41]. The correlation between heavy metals and factors in PCA shows the sources of each contaminant (anthropogenic, natural, or combined). However, it is rather complicated to distinguish the impacts of said elements on the environment [42]. Meanwhile, Co was mainly associated with lithogenic origin from parent materials and anthropogenic sources such as agricultural activities, industry, and household waste. The natural Co concentration in soil was up to $40 \mathrm{mg} \mathrm{kg}^{-1}$. In Europe, the areas that are most exposed to the occurrence of high Co concentrations in the soil of anthropogenic sources are mainly industrial and transport areas [43]. The increase of chromium, cobalt, and nickel in 
TABLE 2: Pearson correlation coefficients of heavy metal concentrations in the soil of shallot fields in Brebes Regency, Central Java, Indonesia.

\begin{tabular}{lccccccc}
\hline & $\mathrm{Pb}$ & $\mathrm{Cd}$ & $\mathrm{Co}$ & $\mathrm{Ni}$ & $\mathrm{Cr}$ & $\mathrm{pH}$ & SOC \\
\hline $\mathrm{Pb}$ & 1 & & & & & & \\
$\mathrm{Cd}$ & 0.025 & 1 & & & & & \\
$\mathrm{Co}$ & -0.063 & -0.071 & 1 & & & \\
$\mathrm{Ni}$ & $0.622^{* *}$ & -0.092 & -0.010 & 1 & & \\
$\mathrm{Cr}$ & $0.577^{* *}$ & $-0.292^{* *}$ & -0.042 & $0.636^{* *}$ & 1 & & \\
$\mathrm{pH}$ & 0.004 & -0.069 & 0.037 & -0.050 & 0.039 & 1 & \\
$\mathrm{SOC}$ & -0.017 & 0.122 & 0.122 & -0.094 & -0.118 & -0.134 & \\
$\mathrm{CEC}$ & 0.015 & $-0.154^{*}$ & 0.108 & 0.039 & 0.141 & $0.202^{* *}$ & -0.043 \\
\hline
\end{tabular}

${ }^{*}$ Significant at $p<0.05 .{ }^{* *}$ Significant at $p<0.01,(-)$ negative correlation.

TABle 3: PCA results of heavy metal concentrations in the soil of shallot fields in Brebes Regency, Central Java, Indonesia.

\begin{tabular}{lccc}
\hline Principal components & Eigenvalues & Proportions of the total variance & Cumulative proportions \\
\hline 1 & 2.2485 & 45.00 & 45.00 \\
2 & 1.1074 & 22.10 & 67.10 \\
3 & 0.9404 & 18.80 & 85.90 \\
4 & 0.3751 & 7.50 & 93.40 \\
5 & 0.3286 & 6.60 & 100.00 \\
\hline
\end{tabular}

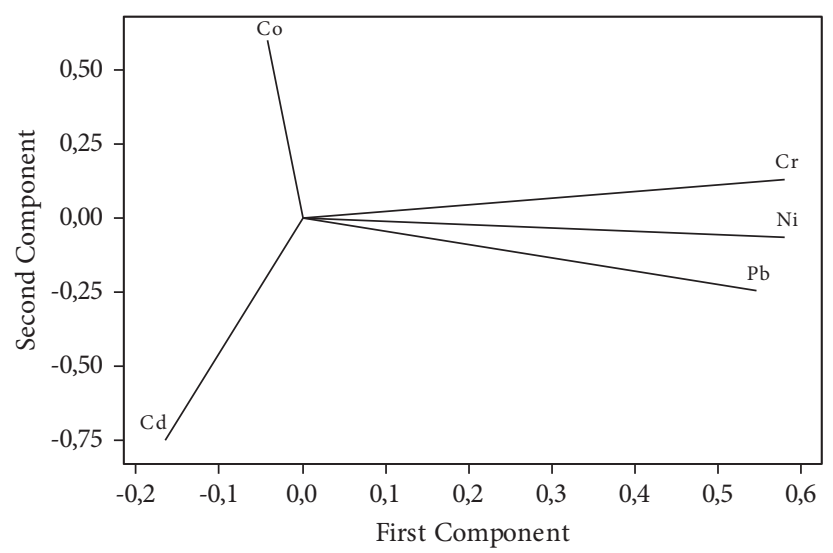

Figure 3: The loading plot of $\mathrm{Pb}, \mathrm{Cd}, \mathrm{Co}, \mathrm{Cr}$, and $\mathrm{Ni}$ from two components (PC1 and PC2).

TABle 4: Principal component (PC) matrix correlating heavy metal concentrations in shallot fields in Brebes Regency, Central Java, Indonesia.

\begin{tabular}{lcc}
\hline Heavy metals & PC1 & PC2 \\
\hline $\mathrm{Pb}$ & 0.546 & -0.246 \\
$\mathrm{Cd}$ & -0.0165 & -0.749 \\
$\mathrm{Co}$ & -0.042 & 0.598 \\
$\mathrm{Ni}$ & 0.580 & -0.068 \\
$\mathrm{Cr}$ & 0.580 & 0.130 \\
\hline
\end{tabular}

Vojvodina, Serbia, is explained by the distribution pattern and the presence of ultramafic and mafic parent rocks and anthropogenic sources from industry in several places [44].

3.4. Cluster Analysis (CA) Results. Hierarchical cluster analysis (HCA) aims to classify a variable and measure its proximity to other variables in the form of a dendrogram: the lower the axis value, the more significant the relationship between said variables [45-47]. Based on the cluster analysis (CA) results (Figure 4), two different clusters were identified: cluster 1 consisted of $\mathrm{Pb}, \mathrm{Ni}$, and $\mathrm{Cr}$, while cluster 2 included $\mathrm{Cd}$ and Co. The HCA results agreed with the PCA findings in that both analyses classified $\mathrm{Pb}, \mathrm{Ni}$, and $\mathrm{Cr}$ into cluster 1 while $\mathrm{Cd}$ and Co into cluster 2 . The first cluster was related to natural factors, while the second was mainly associated with anthropogenic factors.

3.5. Spatial Distribution of Heavy Metals. The spatial distributions of $\mathrm{Pb}, \mathrm{Cd}, \mathrm{Cr}, \mathrm{Co}$, and $\mathrm{Ni}$ concentrations in shallot fields in Brebes Regency, Central Java Province, Indonesia, are presented in Figure 5. $\mathrm{Pb}, \mathrm{Ni}$, and $\mathrm{Cr}$ showed a similar distribution pattern in the shallot fields at lower concentrations, i.e., in the western and middle agricultural areas in 


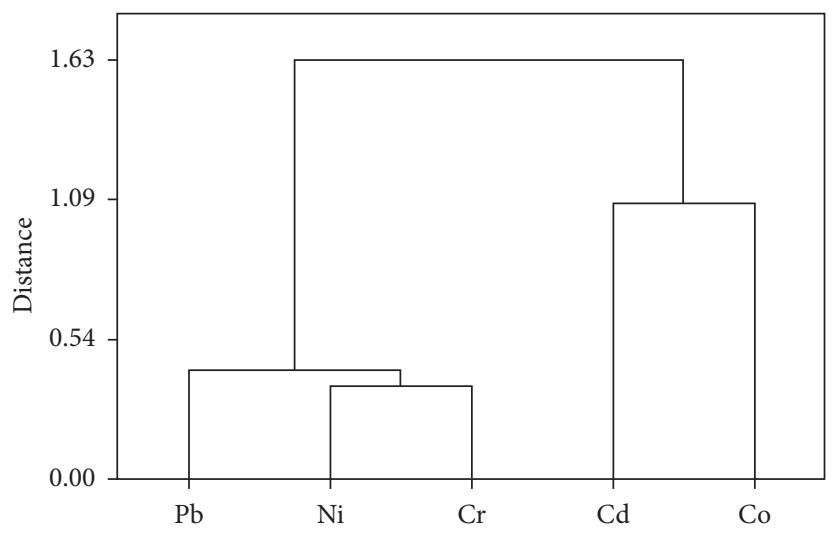

Figure 4: Dendrogram of the five heavy metals observed in the shallot fields (Ward's linkage).
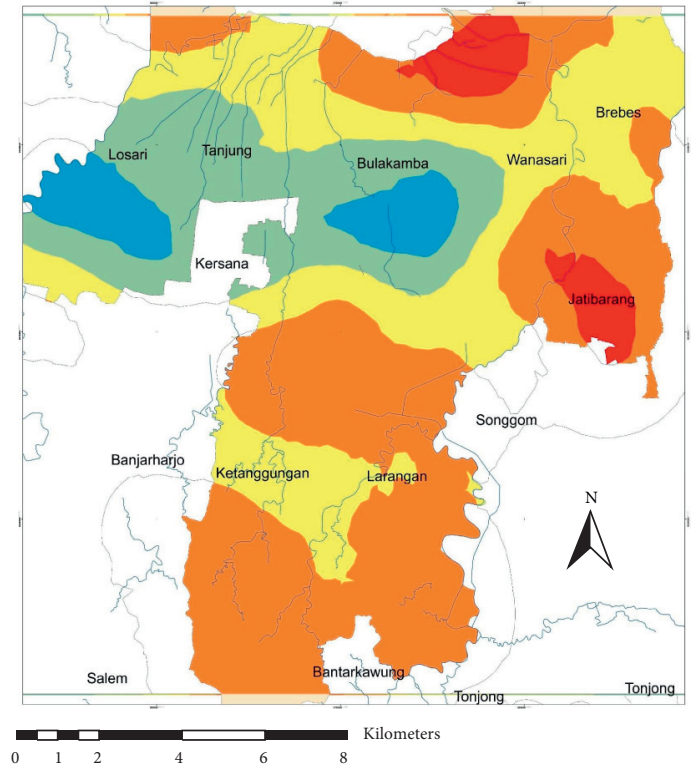

$\mathrm{Pb}\left(\mathrm{mg} / \mathrm{kg}^{-1}\right)$

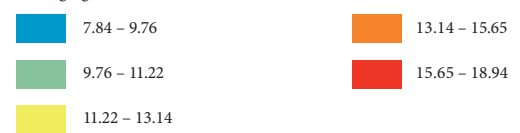

(a)

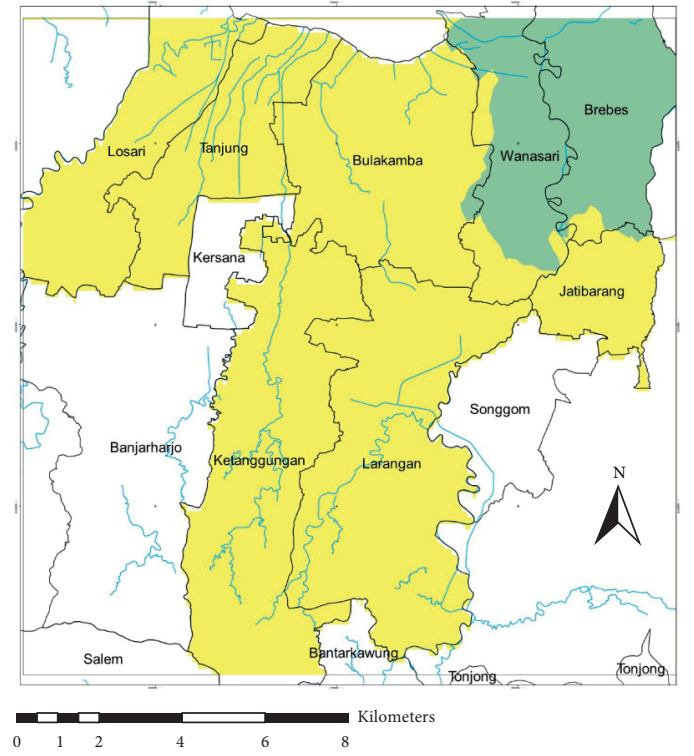

$\mathrm{Cd}\left(\mathrm{mg} / \mathrm{kg}^{-1}\right)$

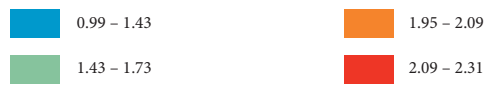

(b)

Figure 5: Continued. 

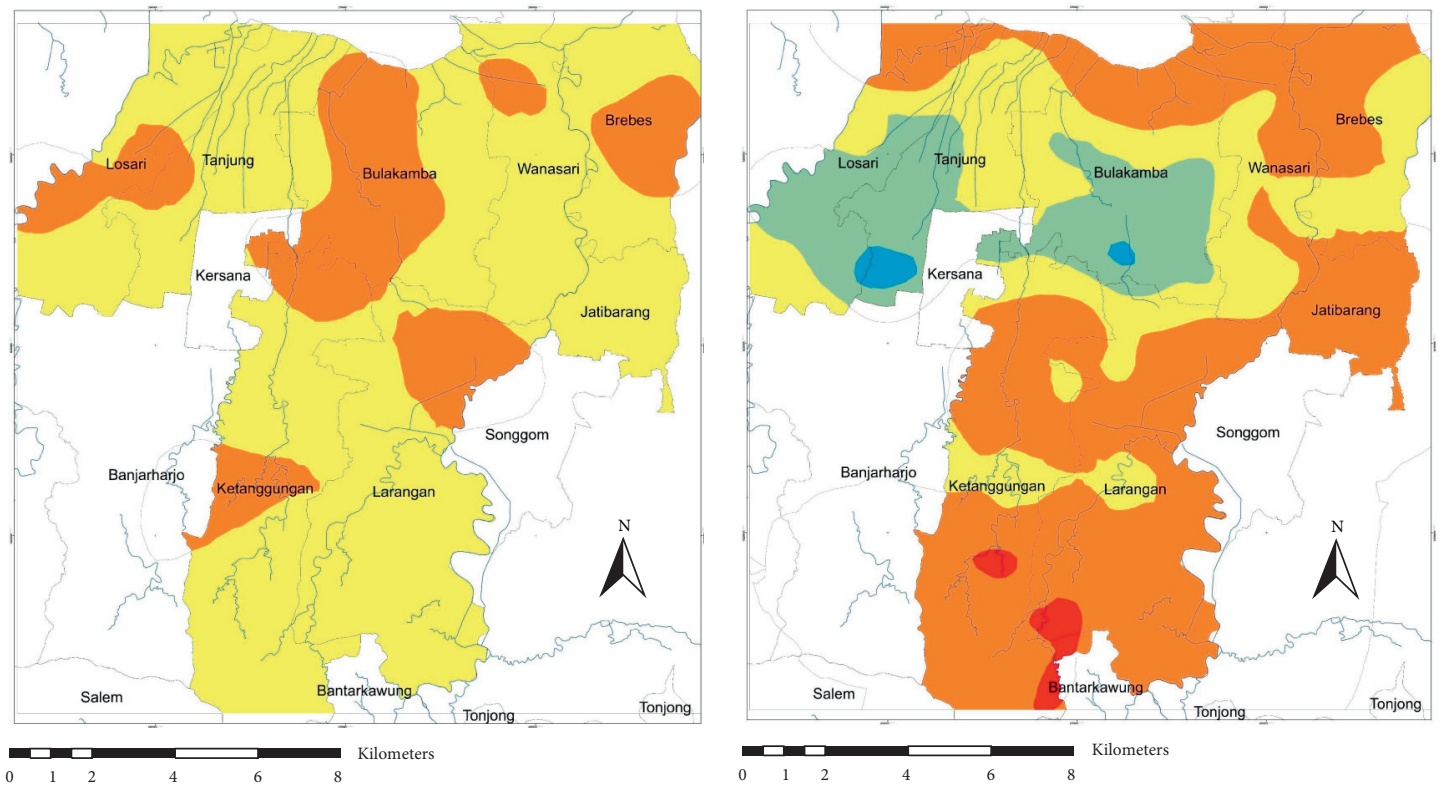

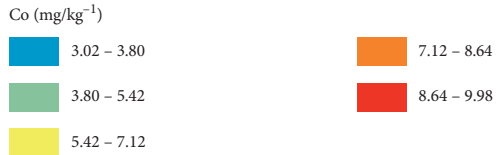

(c)

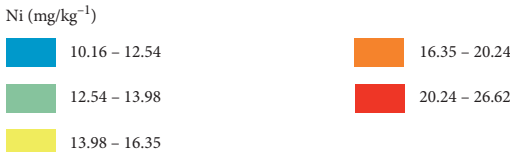

(d)
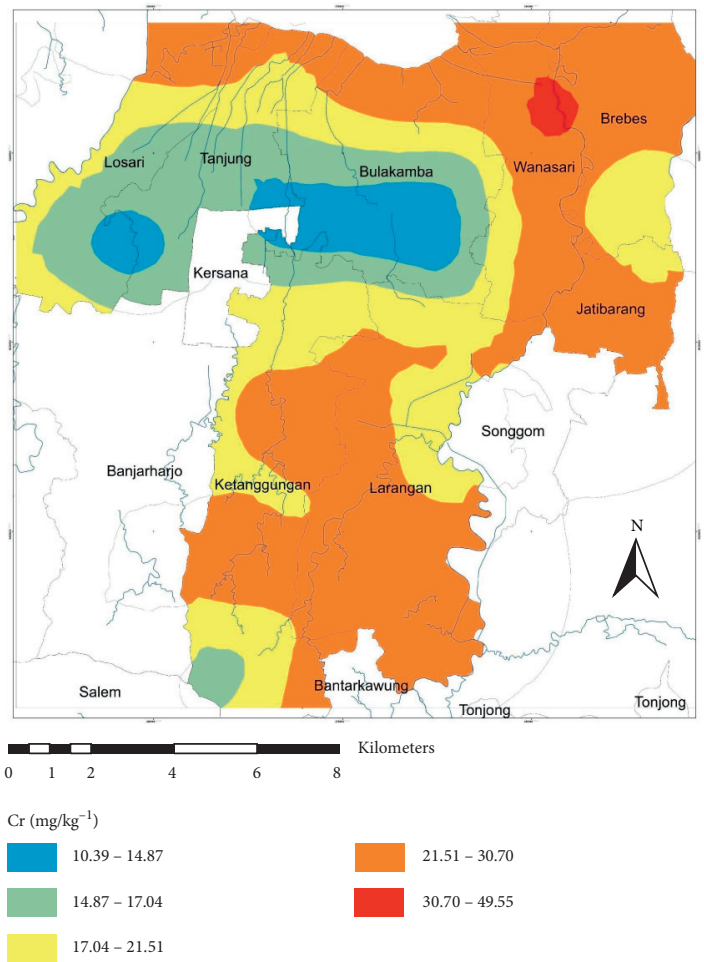

(e)

Figure 5: Spatial distribution maps of heavy metal concentrations in the soil of shallot fields in Brebes Regency, Central Java, Indonesia. 
Losari and Bulakamba, respectively. High $\mathrm{Pb}$ contents were detected in the northern part of the Wanasari and the eastern part of Jatibarang. A high Ni concentration was found in the southern area of Brebes Regency, while a high Cr presence was in the northeast. Natural sources such as lithogenic factors and parent materials are believed to control the $\mathrm{Pb}, \mathrm{Ni}$, and $\mathrm{Cr}$ contents in the agricultural soils [32, 38, 48, 49].

Cd was mostly found in the range of $1.73-1.95 \mathrm{mg} \mathrm{kg}^{-1}$, spreading in almost the entire agricultural soils, except the northeastern part of the regency: Wanasari and Brebes. High $\mathrm{Cd}$ concentrations are caused by agricultural practices such as long-term applications of animal manure, pesticides, and phosphorus fertilizers. In other studies, the presence of $\mathrm{Cd}$ in agricultural soils is significantly correlated with the use of fertilizers (nitrogen, phosphorus, potassium, and fertilizer mixture) [36, 41]. Long-term applications of phosphate fertilizers will increase Cd concentrations in the soil without raising the risk of contamination. In contrast, combined fertilizers (70\% phosphate fertilizer and 30\% animal manure) create a higher risk of Cd contamination in a short time, with a maximum possibility of Cd causing damage to the soil at $55.21 \%$ [50].

The farmer's behavior in shallot cultivation in Brebes Regency, Central Java, was still excessive in using agrochemical. Furthermore, the usage was not in accordance with the recommended dosage in terms of the quality, type, and application method. The use of chemical pesticides and fertilizers that do not match the suggested doses impacts the environment. Besides, nowadays, farmers are also unwilling to use organic fertilizers and ameliorants in shallot cultivation, which are highly recommended to restore soil fertility. The farmer's behavior in the use of pesticides is the key to improving environmental safety. Several factors influenced the behavior. Among others is the level of awareness, attitude, perception of risk, knowledge, and self-efficacy. The majority of farmers applied pesticides without personal protective equipment, so that the pesticides are likely to be exposed to the respiratory system $[51,52]$.

The cobalt concentrations in shallot fields ranged from 3.02 to $9.98 \mathrm{mg} \mathrm{kg}^{-1}$. They were from industrial waste, agricultural activities, household waste, and mining activities. Co can also come from agrochemicals, various organic materials, sewage sludge, food waste, compost, and sewage sludge. The low concentration of Co soil originated from parent materials consists of sediment rock, limestone, claystone, sandstone conglomerate, sandy limestone, and a small amount of andesite $[53,54]$. The development of the industrial area in Brebes Regency is currently increasing. As recorded in Banjarsari, Ketanggungan, and Bulakamba, the increase impacts the land conversion functions, from agriculture to industry, that impact the environment. There are several environmental problems in Brebes Regency, including water, air, and soil pollution. It is due to several factors, including many industries, vehicles emission, climate change, global warming, pesticides application, greenhouse gases, and others.
Co was spread with lower concentrations in the southern part, which is a higher land compared to the northern area of Brebes Regency, Central Java. The heavy metals distribution in soil depends on geogenic, anthropogenic, and climate. Several studies have shown that the distribution of heavy metals is influenced by many factors such as traffic levels, wind direction, and topography. Upland soils are known to be more leached than lowland soils due to higher rainfall and moisture conditions [55, 56]. Heavy metals may result from natural processes, such as redistribution and mobilization from rock weathering by surface and subsurface water, flood, and the processes of chemical and physical reactions occurring in the soil. Floods play a role in transporting heavy metals associated with particulates, especially in highly contaminated catchments. It was found that in the dry season, the concentration of heavy metals was higher in the sediment. In comparison, in the rainy season, the metal concentration was higher in the suspended sediment [57-60].

\section{Conclusions}

The present study provides information on the heavy metal concentration, their possible sources, and distribution in shallot fields in Brebes Regency, Central Java Province, Indonesia. $\mathrm{Pb}, \mathrm{Cd}, \mathrm{Cr}, \mathrm{Co}$, and $\mathrm{Ni}$ metals in the soil were below the critical limit that could affect food safety. The combination of multivariate analysis and geostatistical indicates that $\mathrm{Pb}, \mathrm{Ni}$, and $\mathrm{Cr}$ mainly come from natural sources such as parent materials. Cd comes from anthropogenic sources such as the application of chemical fertilizers, manure, and pesticides. Meanwhile, Co comes from a mixture of natural and anthropogenic sources (agricultural activities, industry, and household waste). This study can be used to establish policies and plan remediation strategies to reduce heavy metal accumulations in agricultural land through environmentally friendly technologies by applying biochar, compost, and biopesticide.

\section{Data Availability}

The data used to support the findings of this study are available from the corresponding author upon request.

\section{Conflicts of Interest}

The authors declare that there are no conflicts of interest.

\section{Acknowledgments}

The research was funded by the Dissertation Program of the Indonesian Agency for Agricultural Research and Development (IAARD) and Ministry of Agriculture (047/Kpts/ KP.320/H.1/11/2019). The study was also supported for publication by the RTA Project (3190/UN1/DITLIT/ DITLIT/PT/2021) at Universitas Gadjah Mada. 


\section{References}

[1] P. Du, Y. Xie, S. Wang et al., "Potential sources of and ecological risks from heavy metals in agricultural soils, Daye City, China," Environmental Science and Pollution Research, vol. 22, no. 5, pp. 3498-3507, 2015.

[2] M. Edelstein and M. Ben-hur, "Heavy metals and metalloids: sources, risks and strategies to reduce their accumulation in horticultural crops," Scientia Horticulturae, vol. 234, pp. 431-444, 2018.

[3] M. Fan, "Distribution and source identification of potentially toxic elements in agricultural soils through high-resolution sampling," Environmental Pollution, vol. 263, Article ID 114527, 2020.

[4] N. Barsova, O. Yakimenko, I. Tolpeshta, and G. Motuzova, "Current state and dynamics of heavy metal soil pollution in Russian Federation-a review," Environmental Pollution, vol. 249, pp. 200-207, 2019.

[5] N. Nanos, J. A. Rodríguez Martín, and R. Martín, "Multiscale analysis of heavy metal contents in soils: spatial variability in the Duero river basin (Spain)," Geoderma, vol. 189, pp. 554-562, 2012.

[6] C. U. I. Xu, "Concentrations of heavy metals in suburban horticultural soils and their uptake by artemisia selengensis," Pedosphere An International Journal, vol. 25, no. 6, pp. 878887, 2015.

[7] X. Fei, R. Xiao, G. Christakos et al., "Comprehensive assessment and source apportionment of heavy metals in Shanghai agricultural soils with different fertility levels," Ecological Indicators, vol. 106, no. 198, Article ID 105508, 2019.

[8] H. N. A. C. Gonc, "Availability of heavy metals (Cd, Pb, and $\mathrm{Cr}$ ) in agriculture from commercial fertilizers," Archives of Environmental Contamination and Toxicology, vol. 64, no. 4, pp. 537-544, 2013.

[9] E. Kelepertzis, "Accumulation of heavy metals in agricultural soils of Mediterranean: insights from Argolida basin, Peloponnese, Greece," Geoderma, vol. 221, pp. 82-90, 2014.

[10] A. Hartono, "Harvesting of residual soil phosphorus on intensive shallot farming in Brebes, Indonesia," AGRIVITA Journal of Agricultural Science, vol. 40, pp. 515-526, 2018.

[11] T. Joko, S. Anggoro, H. R. Sunoko, and S. Rachmawati, "Pesticides usage in the soil quality degradation potential in Wanasari subdistrict, Brebes, Indonesia," Applied and Environmental Soil Science, vol. 2017, Article ID 5896191, , 2017.

[12] B. Waryanto, M. A. Chozin, and E. I. K. Putri, "Environmental efficiency analysis of shallot farming: a stochastic frontier translog regression approach," International Knowledge Sharing Platform, vol. 419 pages, 2014.

[13] A. M. Puspitasari, A. M. Kiloes, S. Hardiyanto, and A. Kiloes, "Farmer's behavior in using pesticides on shallots cultivation in Solok Highlands, West Sumatera," IOP Conference Series: Earth and Environmental Science, vol. 399, Article ID 12116, 2019.

[14] A. N. Ardiwinata and D. Nursyamsi, "Residu pestisida di sentra produksi padi di Jawa Tengah," Pan, vol. 21, no. 1, pp. 39-58, 2012.

[15] R. Ulfa Arini, "Land suitability evaluation of shallot (Allium ascalonicum L.) at production centers in Losari District, Brebes," Journal of Degraded and Mining Lands Management, vol. 6, no. 1, pp. 1505-1511, 2018.

[16] D. M. Susilawati, M. S. Maarif, M. Widiatmaka, and I. Lubis, "Evaluasi kesesuaian dan ketersediaan lahan untuk pengembangan komoditas bawang merah di Kabupaten Brebes, Provinsi Jawa Tengah," Jurnal Pengelolaan Sumberdaya Alam dan Lingkungan (Journal of Natural Resources and Environmental Management), vol. 9, no. 2, pp. 507-526, 2019.

[17] E. Fikri, O. Setiani, and A. Nurjazuli, "Association between pesticide exposure with arsenic (As) concentration and the incidence of anemia: study: the farmer's pesticide sprayer in Brebes)," Jurnal Kesehatan LIngkungan Indonesia, vol. 11, no. 1, pp. 29-37, 2012.

[18] W. Roessali, E. D. Purbajanti, and T. Dalmiyatun, "The adoption behavior and its influenced factors of true shallot seed technology in Central Java," IOP Conference Series: Earth and Environmental Science, vol. 250, no. 1, 2019.

[19] E. Hartini and U. Dian, "Kadar plumbum (Pb) dalam umbi bawang merah," Jurnal Visikes, vol. 10, no. 1, pp. 69-75, 2011.

[20] J. Lv and Y. Liu, "An integrated approach to identify quantitative sources and hazardous areas of heavy metals in soils," The Science of the Total Environment, vol. 646, pp. 19-28, 2019.

[21] J. Huang, S. Peng, X. Mao et al., "Source apportionment and spatial and quantitative ecological risk assessment of heavy metals in soils from a typical Chinese agricultural county," Process Safety and Environmental Protection, vol. 126, pp. 339-347, 2019.

[22] M. A. Gharaibeh, B. Marschner, S. Heinze, and N. Moos, "Geoderma Regional Spatial distribution of metals in soils under agriculture in the Jordan Valley," Geoderma Reg, vol. 20, Article ID e00245, 2020.

[23] ISRI, K. T. Analisis, A. Tanaman, and dan Pupuk, Bogor, Indonesia, Indonesian Soil Research Institute, Bogor, Indonesia, 2009.

[24] A. Keshavarzi and V. Kumar, "Spatial distribution and potential ecological risk assessment of heavy metals in agricultural soils of Northeastern Iran," Geology, Ecology, and Landscapes, vol. 4, no. 2, pp. 87-103, 2020.

[25] S. Tong, H. Li, W. Li, M. Tudi, and L. Yang, "Concentration, spatial distribution, contamination degree and human health risk assessment of heavy metals in urban soils across China between 2003 and 2019-a systematic review," International Journal of Environmental Research and Public Health, vol. 17, no. 9, pp. 1-22, 2020.

[26] F. Wang, Q. Guan, J. Tian et al., "Contamination characteristics, source apportionment, and health risk assessment of heavy metals in agricultural soil in the Hexi Corridor," $\mathrm{Ca}$ tena, vol. 191, Article ID 104573, 2020.

[27] A. Kabata-Pendias, Trace Elements in Soils and Plants, CRC Press, Boca Raton, FL, USA, 2011.

[28] C. Fu, H. Zhang, C. Tu, L. Li, X. Liu, and Y. Luo, "Spatial interpolation of orchard soil $\mathrm{pH}$ using soil type and planting duration as auxiliary information," Pedosphere, vol. 30, no. 5, pp. 628-637, 2020.

[29] H. Xu and C. Zhang, "Investigating spatially varying relationships between total organic carbon contents and $\mathrm{pH}$ values in European agricultural soil using geographically weighted regression," The Science of the Total Environment, vol. 752, Article ID 141977, 2021.

[30] A. Kicińska and J. Wikar, "Ecological risk associated with agricultural production in soils contaminated by the activities of the metal ore mining and processing industry - example from southern Poland," Soil and Tillage Research, vol. 205, 2021.

[31] E. F. Solly, V. Weber, S. Zimmermann, L. Walthert, F. Hagedorn, and M. W. I. Schmidt, "A critical evaluation of the relationship between the effective cation exchange capacity and soil organic carbon content in swiss forest soils," Frontiers in Forests and Global Change, vol. 3, 2020.

[32] H. Baltas, M. Sirin, E. Gökbayrak, and A. E. Ozcelik, "A case study on pollution and a human health risk assessment of 
heavy metals in agricultural soils around Sinop province, Turkey," Chemosphere, vol. 241, Article ID 125015, 2020.

[33] L. Cai, Z. Xu, P. Bao et al., "Multivariate and geostatistical analyses of the spatial distribution and source of arsenic and heavy metals in the agricultural soils in Shunde, Southeast China," Journal of Geochemical Exploration, vol. 148, pp. 189-195, 2015.

[34] A. Mamut, M. Eziz, and A. Mohammad, "Pollution and ecological risk assessment of heavy metals in farmland soils in Yanqi County, Xinjiang, Northwest China," Eurasian Soil Science, vol. 51, no. 8, pp. 985-993, 2018.

[35] Y. Shan, M. Tysklind, F. Hao, W. Ouyang, S. Chen, and C. Lin, "Identification of sources of heavy metals in agricultural soils using multivariate analysis and GIS," Journal of Soils and Sediments, vol. 13, no. 4, pp. 720-729, 2013.

[36] S. Yang, Y. Qu, J. Ma et al., "Comparison of the concentrations, sources, and distributions of heavy metal(loid)s in agricultural soils of two provinces in the Yangtze River Delta, China," Environmental Pollution, vol. 264, Article ID 114688, 2020.

[37] Z. Cui, Y. Wang, N. Zhao, R. Yu, G. Xu, and Y. Yu, "Spatial distribution and risk assessment of heavy metals in paddy soils of yongshuyu irrigation area from Songhua river basin, Northeast China," Chinese Geographical Science, vol. 28, no. 5, pp. 797-809, 2018.

[38] A. Hani and E. Pazira, "Heavy metals assessment and identification of their sources in agricultural soils of Southern Tehran, Iran," Environmental Monitoring and Assessment, vol. 176, no. 1-4, pp. 677-691, 2011.

[39] J. Zhang, Y. Wang, J. Liu, Q. Liu, and Q. Zhou, "Multivariate and geostatistical analyses of the sources and spatial distribution of heavy metals in agricultural soil in Gongzhuling, Northeast China," Journal of Soils and Sediments, vol. 16, no. 2, pp. 634-644, 2016.

[40] J. A. Rodríguez, N. Nanos, J. M. Grau, L. Gil, and M. LópezArias, "Multiscale analysis of heavy metal contents in Spanish agricultural topsoils," Chemosphere, vol. 70, no. 6, pp. 1085-1096, 2008.

[41] T. Shi, Y. Zhang, Y. Gong et al., "Status of cadmium accumulation in agricultural soils across China (1975-2016): from temporal and spatial variations to risk assessment," Chemosphere, vol. 230, pp. 136-143, 2019.

[42] C. Sun, J. Liu, Y. Wang, L. Sun, and H. Yu, "Multivariate and geostatistical analyses of the spatial distribution and sources of heavy metals in agricultural soil in Dehui, Northeast China," Chemosphere, vol. 92, no. 5, pp. 517-523, 2013.

[43] M. Kosiorek and M. Wyszkowski, "Remediation of cobaltcontaminated soil using manure, clay, charcoal, zeolite, calcium oxide, main crop (Hordeum vulgare 1.), and after-crop (synapis alba 1.)," Minerals, vol. 10, no. 5, 2020.

[44] M. M. P. Spahić, "Natural and anthropogenic sources of chromium, nickel, and cobalt in soils impacted by agricultural and industrial activity (Vojvodina, Serbia)," Journal of Environmental Science and Health, Part A Toxic/Hazardous Substances and Environmental Engineering, vol. 4, no. 3, pp. 219-230, 2018.

[45] N. El Khodrani, S. Omrania, A. Zouahri et al., "Spatial distribution and mapping of heavy metals in agricultural soils of the Sfafaa region (Gharb, Morocco)," Materials Today: Proceedings, vol. 13, pp. 832-840, 2019.

[46] E. Mahmoudabadi, F. Sarmadian, and R. Nazary Moghaddam, "Spatial distribution of soil heavy metals in different land uses of an industrial area of Tehran (Iran)," International journal of Environmental Science and Technology, vol. 12, no. 10, pp. 3283-3298, 2015.
[47] A. M. Astel, L. Chepanova, and V. Simeonov, "Soil contamination interpretation by the use of monitoring data analysis," Water, Air, \& Soil Pollution, vol. 216, no. 1-4, pp. 375-390, 2011.

[48] H. T. Davis, C. M. Aelion, S. Mcdermott, and A. B. Lawson, "Identifying natural and anthropogenic sources of metals in urban and rural soils using GIS-based data, PCA, and spatial interpolation," Environmental Pollution, vol. 157, no. 8-9, pp. 2378-2385, 2009.

[49] M. Amir, H. Bhuiyan, S. Chandra, A. Rakib, and B. Baran, "Chemosphere Enrichment, sources and ecological risk mapping of heavy metals in agricultural soils of Dhaka district employing SOM, PMF and GIS methods," Chemosphere, vol. 263, Article ID 128339, 2021.

[50] Z. Zhuang, H. Y Mu, P. N Fu et al., "Accumulation of potentially toxic elements in agricultural soil and scenario analysis of cadmium inputs by fertilization: a case study in Quzhou county," Journal of Environmental Management, vol. 269, Article ID 110797, 2020.

[51] C. A. Damalas and S. D. Koutroubas, "Farmers' behaviour in pesticide use: a key concept for improving environmental safety," Current Opinion in Environmental Science \& Health, vol. 4, pp. 27-30, 2018.

[52] A. I. Sankoh, R. Whittle, K. T. Semple, K. C. Jones, and A. J. Sweetman, "An assessment of the impacts of pesticide use on the environment and health of rice farmers in Sierra Leone," Environment International, vol. 94, pp. 458-466, 2016.

[53] W. Purbalisa and T. Dewi, "Remediasi tanah tercemar kobalt (co) menggunakan bioremediator dan amelioran," Jurnal Tanah dan Sumberdaya Lahan, vol. 6, no. 2, pp. 1237-1242, 2019.

[54] D. M. W. Paputri, C. O. Handayani, P. Sukarjo, S. Rianto, and F. Purnariyanto, "Identification of cobalt in paddy fields in karawang and bekasi districts,", IOP Conference Series: Earth and Environmental Science, vol. 648, no. 1, 2021.

[55] Y. Dong, S. Liu, Y. Sun, Y. Liu, and F. Wang, "Effects of landscape features on the roadside soil heavy metal distribution in a tropical area in Southwest China," Applied Sciences, vol. 11, no. 4, pp. 1-13, 2021.

[56] K. S. Rawat, R. Kumar, and S. K. Singh, "Topographical distribution of cobalt in different agro-climatic zones of Jharkhand state, India," Geology, Ecology, and Landscapes, vol. 3, no. 1, pp. 14-21, 2019.

[57] C. I. A. Aflizar, C. I. Alarima, and T. Masunaga, "Effect of soil erosion and topography on distribution of cadmium (Cd) in Sumani watershed, West Sumatra, Indonesia," MATEC Web of Conferences, vol. 229, 2018.

[58] D. Ciszewski and T. M. Grygar, "A review of flood-related storage and remobilization of heavy metal pollutants in river systems," Water, Air, \& Soil Pollution, vol. 227, no. 7, 2016.

[59] S. P. Indraratne and D. Kumaragamage, "Flooding-induced mobilization of potentially toxic trace elements from uncontaminated, calcareous agricultural soils," Canadian Journal of Soil Science, vol. 98, no. 1, pp. 103-113, 2017.

[60] J. Ponting, T. J. Kelly, A. Verhoef, M. J. Watts, and T. Sizmur, "The impact of increased flooding occurrence on the mobility of potentially toxic elements in floodplain soil-a review," The Science of the Total Environment, vol. 2020, Article ID 142040,, 2020. 